\title{
PRIMUM NON NOCERE...? TOŻSAMOŚĆ ZWOLENNIKÓW ORIENTACJI AUSTRO-POLSKIEJ W OKRESIE I WOJNY ŚWIATOWEJ
}

\author{
Mateusz Drozdowski \\ Tychy
}

\author{
ABSTRACT \\ PRIMUM NON NOCERE...? IDENTITY OF THE FOLLOWERS \\ OF THE AUSTRO-POLISH SOLUTION DURING WORLD WAR I
}

The aim of the article is to analyze the national identity of the Polish politicians active in a selfgoverning Galicia who were supporters of the so-called Austro-Polish solution. This political idea was based on a plan to reconstruct Polish sovereignty in cooperation with the Habsburg monarchy. The majority of followers of the Austro-Polish solution were members of one political party: the Cracow conservatives. After the outbreak of World War I the idea was promoted by the Supreme National Committee, an organization that was created as a political and logistic background of the Polish Legions, the semi-independent Polish troops that fought as a part of the Austro-Hungarian military.

The research is primarily focused on the question whether it is possible to describe the identity of these politicians as Polish or Austrian, or was it a kind of combination of the two? The paper analyzes the attitude of Władysław Leopold Jaworski, Leon Biliński and Michał Bobrzyński, three politicians who, between 1914 and 1918, played a crucial role in all attempts to realize and promote the Austro-Polish idea. Their dilemmas were precisely examined on the basis of memoires, speeches and historical studies as well as the archives. The author claims that the attitude of the three politicians towards the Austro-Hungarian Empire undoubtedly contained an emotional component. It means that describing these politicians as Austro-Polish patriots seems to be absolutely justified.

Key words: Austro-Polish solution, Galicia, Wladyslaw Leopold Jaworski, Leon Bilinski, Michal Bobrzynski.

Słowa kluczowe: orientacja polsko-austriacka, Galicja, Władyslaw Leopold Jaworski, Leon Biliński, Michał Bobrzyński. 
Ile Austriaka było w Polaku? Pytanie to, choć nieco banalizuje złożoną i wielowątkową kwestię tożsamości polskich mieszkańców Galicji, wydaje się mimo wszystko uzasadnione. Nie ulega bowiem wątpliwości, że dla ogromnej większości społeczeństwa tego kraju monarchia habsburska okazała się czymś więcej niż tylko zaborcą, którego należało tolerować, bądź to ze względu na przyjęcie postawy politycznego wyrachowania, bądź też z powodu zwyczajnego braku innej możliwości. Dla galicyjskich Polaków Austria była państwem, z którym się w pewnej mierze identyfikowali. Stanowiła ona przede wszystkim niezwykle konkretną i - wydawałoby się - absolutnie trwałą rzeczywistość polityczną. Jej ewentualnego końca nie przewidywał właściwie nikt ${ }^{1}$. Monarchia habsburska nie tyle budziła jakieś wzniosłe, patriotyczne uczucia, ile raczej porządkowała ludziom rzeczywistość, dając poczucie istnienia państwa, w którym można było spokojnie i po swojemu - a więc „po polsku" - żyć. Austrii raczej nie kochano, ale można się było do niej przyzwyczaić, a nawet ją polubić. Jak się okazało, po jej upadku zaczęto nawet o niej myśleć z pewnym sentymentem².

O stosunku galicyjskich Polaków do Austrii można by mówić wiele. Jeśli chodzi o ogół społeczeństwa, to trzeba jednak jasno powiedzieć, że formułowanie jednoznacznych wniosków na temat jego lojalizmu wymagałoby znacznie szerszych i bardziej kompleksowych badań niż te przeprowadzane dotychczas. Rzecz jasna, dysponujemy wieloma wzmiankami, które sugerują jakąś formę emocjonalnego stosunku różnych grup społecznych do monarchii Habsburgów. Przytaczać możemy niezliczone cytaty z prasy, różnego rodzaju przemówień i uroczystości, w których jest mowa o niezachwianej wierności Galicjan w stosunku do cesarza oraz państwa. Wiemy, że udające się w 1914 roku na front oddziały austro-węgierskiej armii żegnano jako „nasze wojsko"3. Owe świadectwa to jednak wciąż za mało, aby w sposób naukowy wypowiedzieć się na temat całościowego obrazu.

Nieco lepiej sprawa wygląda, jeśli chodzi o galicyjskie elity - polityczne, finansowe, czy też wreszcie intelektualne. Tu dysponujemy dość poważnym zasobem źródeł oraz faktów. Powszechnie wiadomo, że autonomia galicyjska stanowiła rezultat pewnego rodzaju kompromisu zawartego między koroną oraz polską elitą polityczną. Porozumienie to okazało się nader trwałe, również w sferze ideologicznej. Słowa skierowanego do Franciszka Józefa I adresu „Przy Tobie najjaśniejszy Panie stoimy i stać chcemy" stały się nie tylko kolejnym politycznym hasłem, ale także synonimem postawy przynajmniej dwóch pokoleń. Za swoisty fenomen można uznać nie tylko zwykły lojalizm galicyjskich elit, ale też ich głębokie zaangażowanie w politykę monarchii habsburskiej, i to na najwyższym szczeblu. Dwóch Polaków, Alfred Potocki oraz Kazimierz Badeni, pełniło funkcję premiera, kilkudziesięciu innych dzierżyło teki ministerialne ${ }^{4}$. Do grupy tej należały postacie wywierające na polity-

1 K. Srokowski, N.K.N. Zarys historii Naczelnego Komitetu Narodowego, Kraków 1923, s. 41-47.

2 Zob. J. Purchla, Galicja po Galicji, czyli o niezwyktości mitu zaginionego królestwa [w:] Mit Galicji, red. J. Purchla, W. Kos, Ż. Komar, M. Rydiger, W.M. Schwarz, Kraków 2014, s. 89-93.

3 Szerzej na ten temat zob. J.Z. Pająk, Od autonomii do niepodległości. Ksztaltowanie się postaw politycznych i narodowych społeczeństwa Galicji w warunkach Wielkiej Wojny 1914-1918, Kielce 2012.

4 W. Łazuga, Kalkulować. Polacy na szczytach c.k. monarchii, Poznań 2013, s. 9. 
kę monarchii realny wpływ, między innymi minister spraw wewnętrznych Agenor Gołuchowski, czy też Julian Dunajewski, który funkcję ministra skarbu pełnił aż 11 lat (1880-1891), wyciągając przy tym Austrię z głębokiej, ekonomicznej zapaści. Tak samo długi okres (lata 1895-1906) tekę ministra spraw zagranicznych dzierżył Agenor Gołuchowski młodszy, który walczył o interesy monarchii z autentycznym zaangażowaniem, wielokrotnie deklarując przy tym swój gorący „habsburski” patriotyzm. Grzmiał na przykład: „dbamy o dobro Austrii - ognisko pokoju mogące dawać przykład całemu światu"s.

Takie przykłady można by mnożyć. W niniejszym tekście chciałbym się jednak skoncentrować na pewnej bardzo konkretnej grupie działaczy politycznych - na zwolennikach orientacji na Austrię w czasie I wojny światowej, a także w okresie bezpośrednio ją poprzedzającym. Dlaczego? Ponieważ był to jeden jedyny moment, kiedy pojawiła się realna szansa na to, aby ze związku Galicji z Austrią wyewoluowało coś znacznie poważniejszego niż tylko zgodna koegzystencja odległej prowincji z metropolią. Samorządna, autonomiczna i rozwijająca polskie życie narodowe Galicja przez długie lata widziana była jako „polski Piemont”, faza autonomiczna miała więc stanowić zaledwie wstęp do powstania znacznie poważniejszego bytu politycznego ${ }^{6}$. Możliwość taka pojawiła się realnie tylko raz - w momencie wybuchu I wojny światowej. Idea austro-polska nie została, jak wiemy, zrealizowana, ale bez wątpienia stanowiła przez pewien czas bardzo poważną propozycję polityczną. Warto sobie zadać pytanie, jak wyglądała tożsamość ludzi, którzy podjęli na jej rzecz konkretne działania. W co właściwie wierzyli? W Polskę? A może też w Austrię? $\mathrm{W}$ praktyce sprowadza się to do pytania, czy zaangażowanie w realizację koncepcji austro-polskiej było tylko rezultatem ich zimnej kalkulacji oraz przyjęcia, że jest to najlepszy możliwy scenariusz realizacji polskich aspiracji, czy też działanie to zawierało w sobie komponent emocjonalny? Primum non nocere ... „Po pierwsze nie szkodzić" - taką dewizę stosunku galicyjskich elit do Austrii ukuł wybitny znawca tego okresu prof. Waldemar Łazuga. Czy aby w tym wszystkim nie chodziło jednak o coś więcej?

Najpierw musimy jednak uporządkować pewne fakty i odpowiedzieć na pytanie: co dokładnie należy rozumieć przez tak zwaną orientację austro-polską? Niezwykle trudno odróżnić ją bowiem od zwykłych deklaracji lojalności w stosunku do państwa i władcy. Otóż pojęciem tym określać możemy zwolenników bardzo konkretnej, politycznej wizji. Odbudowanie polskiej państwowości w ramach monarchii Habsburgów miało się odbyć poprzez zjednoczenie - po wygranej wojnie z Rosją - ziem zaboru austriackiego oraz Królestwa Polskiego i powołanie do życia nowego bytu politycznego, cieszącego się daleko większym stopniem suwerenności niż dotychczasowa Galicja. Realizacja tego planu oznaczałaby rzecz jasna pominięcie z przyczyn geopolitycznych zaboru pruskiego i nie pozwalałaby osiągnąć pełnej niepodległości, niemniej jednak stanowiłaby istotny krok naprzód, stwarzając znacznej

Ibidem, s. 95-100, 208-220.

6 R.R. Ludwikowski, Szkice na temat galicyjskich ruchów i myśli politycznej (1848-1892), Warszawa 1980, s. 167-168. 
części narodu najkorzystniejsze warunki bytowania w kraju względnie liberalnym i posiadającym największą możliwą wówczas autonomię ${ }^{7}$.

Jeśli chodzi z kolei o charakter związku odtworzonej Polski z Austro-Węgrami, to zasadniczo rozważano trzy możliwości: unii personalnej, trializmu oraz subdualizmu ${ }^{8}$. Pierwsza z nich zakładała, że jedynym łącznikiem z naddunajską monarchią pozostawałby władca z dynastii Habsburgów. Druga opcja oznaczała ustanowienie związku z Cesarstwem Austriackim na tych samych zasadach, co z Królestwem Węgier, a więc stworzenie państwa trialistycznego. Trzecie rozwiązanie uznawać można za minimalistyczne, zakładało bowiem utworzenie autonomicznego państwa polskiego wyłącznie w ramach austriackiej części monarchii.

Nie zagłębiając się już bardziej w zawiłości tych geopolitycznych koncepcji, należy stwierdzić, że tylko część ugrupowań aktywnych na galicyjskiej scenie politycznej w sposób jednoznaczny opowiadała się za tym rozwiązaniem. Wszystkie bez wyjątku stronnictwa, łącznie z galicyjską Narodową Demokracją, prześcigały się $\mathrm{w}$ swoim lojalizmie, lecz koncepcję austro-polską w praktyce propagowali niemal wyłącznie krakowscy konserwatyści, bezpośrednio wywodzący się ze słynnego obozu stańczyków. Ideę tę zasadniczo popierali też bliscy konserwatystom demokraci. O pewnych austro-polskich wątkach można też było mówić w przypadku socjaldemokratów. Myśl ta pozostawała natomiast obca drugiemu, obok stronnictwa krakowskiego, konserwatywnemu środowisku, jakie stanowili Podolacy, nie wspominając już o Narodowej Demokracji. Interesujących nas kwestii nie poruszały też stronnictwa chłopskie.

Sprawą niezwykle kontrowersyjną pozostaje też pytanie, czy do orientacji austro-polskiej należy zaliczać środowisko niepodległościowców, inaczej irredentystów, skupionych wokół Józefa Piłsudskiego, Komisji Skonfederowanych Stronnictw Niepodległościowych (KSSN) oraz organizacji strzeleckich, które ponad wszelką wątpliwość współpracowało z austriackim wywiadem. Wszystko wskazuje na to, że ów sojusz miał jednak charakter taktyczny, doraźny i wynikał przede wszystkim z faktu posiadania wspólnego wroga - Cesarstwa Rosyjskiego9. Zwolennikom Piłsudskiego daleko było jednak do jakiegokolwiek entuzjazmu zarówno w stosunku do Austro-Węgier, jak i lansowanej przez galicyjskich polityków wizji odbudowy polskiej państwowości we współpracy z naddunajską monarchią.

Po wybuchu I wojny światowej głównym ośrodkiem, który w sposób jawny i na niezwykle szeroką skalę prowadził propagandę na rzecz rozwiązania austro-polskiego, stał się Naczelny Komitet Narodowy (NKN). Organizacja ta powołana została do życia jako polityczne oraz przede wszystkim organizacyjne zaplecze Legionów

K. Srokowski, op. cit., s. 48-49, za: R. Król-Mazur, Idea odrodzonego państwa polskiego w pogladach galicyjskich ugrupowań politycznych do utworzenia Naczelnego Komitetu Narodowego, „Politeja” 2010, nr 14, s. 273.

8 Szerzej na temat koncepcji odbudowy polskiej państwowości we współpracy z Austro-Węgrami: H. Batowski, Rozpad Austro-Węgier 1914-1918, Kraków 1982, s. 269-271.

9 W. Suleja, Józef Pitsudski, Wrocław 2005, s. 102-103. 
Polskich ${ }^{10}$. Stanowiła ona początkowo porozumienie absolutnie wszystkich stronnictw Galicji i koncentrowała się niemal wyłącznie na wystawianiu kolejnych, polskich oddziałów ochotniczych. W miarę upływu czasu Komitet został jednak całkowicie zdominowany przez krakowskich konserwatystów, przede wszystkim w postaci ówczesnego prezesa NKN Władysława Leopolda Jaworskiego, co zaowocowało przyjęciem bardzo jednoznacznego, austro-polskiego programu, o którego realizację, szczególnie w latach 1915-1916, intensywnie zabiegano na wiedeńskim dworze, w kręgach rządowych, a także propagowano w polskim społeczeństwie oraz za granicą.

Rozwiązanie austro-polskie nie doczekało się ostatecznie realizacji. Nie udało się przekonać do niego ani Austriaków, ani polskiego społeczeństwa, z wyjątkiem może, i to tylko do pewnego momentu, mieszkańców Galicji. Niepowodzenie przypieczętował dodatkowo Akt 5 listopada 1916 roku, który poprzez powołanie uzależnionego od państw centralnych Królestwa Polskiego niweczył szansę na zjednoczenie ziem zaboru rosyjskiego i austriackiego ${ }^{11}$. W 1917 roku likwidacji uległy też Legiony Polskie, uchodzące za jedyny wyraźny, polityczny sukces opcji prohabsburskiej. Swoisty „gwóźdź do trumny” stanowił ostatecznie traktat brzeski, podpisany w lutym 1918 roku przez państwa centralne z Ukraińską Republiką Ludową, w wyniku którego społeczeństwo polskie, łącznie z Polakami żyjącymi w Galicji, pozbyło się jakichkolwiek proaustriackich czy też proniemieckich sentymentów.

Takie są ogólne fakty historyczne. Przyjrzyjmy się teraz nieco dokładniej środowisku, które ową austro-polską koncepcję wypracowało. W praktyce, jak już wspominaliśmy, należałoby je sprowadzić do krakowskich konserwatystów. Jako kontynuatorzy stańczyków stanowili oni ugrupowanie, które przez niemal cały czas istnienia autonomii sprawowało władzę - można powiedzieć, że byli oni wręcz kwintesencją galicyjskiej polityki ${ }^{12}$. Wynikało to z faktu, że przez 50 lat związani z nimi działacze oraz intelektualiści kształtowali zasadniczy polityczny dyskurs Galicji, a także bezpośrednio wpływali na charakterystyczny sposób działania ogółu tamtejszych polityków. Ich ideologia, jak pisał jeden z komentatorów ówczesnego życia politycznego Konstanty Srokowski, miała „charakter wypróbowanej, niezawodnej i jedynie wskazanej"13.

10 Szerzej o powstaniu Naczelnego Komitetu Narodowego: K. Srokowski, op. cit., s. 120-157; M. Sokolnicki, Rok czternasty, Londyn 1961, s. 197-203; J. Dąbrowski, Wielka Wojna 1914-1918, t. 1, Warszawa 1937, s. 155-156; W. Sulej a, Orientacja austro-polska w latach I wojny światowej (do aktu 5 listopada 1916 roku), Wrocław 1992, s. 42-56. Na temat Naczelnego Komitetu Narodowego zob.: M. Drozdowski, Udział Naczelnego Komitetu Narodowego w tworzeniu zaplecza logistyczno-organizacyjnego Legionów Polskich [w:] Prace Komisji Historii Wojen i Wojskowości PAU, t. 9, red. W. R oj e k, Kraków 2015, s. 29-44.

11 W. Suleja, Orientacja..., s. 324-326.

12 Na temat konserwatystów krakowskich oraz galicyjskich elit władzy, zob.: A.A. Zięba, Polacy taktyczni a Polacy nietaktowni. Doświadczenie historyczne a świadomość polityczna elit władzy w Galicji w przededniu niepodległości [w:] Stan świadomości narodowej Polaków w przededniu niepodległości, red. J. Machnik, W. Rojek, Kraków 2010, s. 57-72.

13 K. Srokowski, op. cit., s. 18. 
Przez większą cześć okresu autonomicznego krakowscy konserwatyści stanowili bardziej środowisko niż partię polityczną. Formalna instytucjonalizacja ugrupowania nastąpiła dopiero w 1907 roku, kiedy powstało Stronnictwo Prawicy Narodowej. Należy również zaznaczyć, że na początku XX wieku określenia „konserwatyści krakowscy” nie stosowano wymiennie z nazwą „stańczycy”. Ta ostatnia zarezerwowana była wyłącznie dla pokolenia „Teki Stańczyka”14. Działacze okresu poprzedzającego I wojnę światową chętniej określali się jako „,neokonserwatyści”. W szerokim odczuciu społecznym stanowili oni jednak wciąż to samo „stronnictwo krakowskie”. Neokonserwatyści skupiali się początkowo w założonym w 1895 roku Klubie Społecznym ${ }^{15}$. Do ich grona należeli: Piotr i Antoni Górscy, Władysław Leopold Jaworski, Adam Krzyżanowski, Stanisław Estreicher i Jan Hupka ${ }^{16}$. W stosunku do swoich poprzedników byli niezwykle krytyczni, szczególnie jeśli chodzi o stan galicyjskiej gospodarki ${ }^{17}$. Nie zmienia to jednak faktu, że pod względem światopoglądowym pozostawali częścią ruchu stańczykowskiego, „,byli odroślą na pniu dawnego konserwatyzmu krakowskiego, szkołą przyszłej kadry politycznej, która przez podjęcie wspomnianej wyżej problematyki uzupełniała (a czasem krytykowała) idee, które przez ich nauczycieli zostały ongiś zaniedbane lub źle ujęte"18. Najwybitniejszą postacią obozu neokonserwatystów, a zarazem przywódcą stronnictwa krakowskiego w latach poprzedzających wybuch I wojny światowej był Władysław Leopold Jaworski ${ }^{19}$.

Zjawiskiem niejako definiującym ugrupowanie stańczyków pozostawał ich ścisły związek z krakowską szkołą historyczną ${ }^{20}$. Nie sposób określić, który z elementów miał charakter pierwotny, a który wtórny: postawa polityczna czy też może refleksja historyczna? Powszechnie przyjmuje się, że to naukowa analiza dziejów stała się punktem wyjścia do przyjęcia przez nich określonej opcji politycznej. Niezależnie od tych dywagacji jedno wydaje się pewne: elementem wyróżniającym konserwatystów krakowskich na tle nie tylko polskiej polityki było ,zjawisko połączenia najwyższych kwalifikacji naukowych w zakresie historii z faktycznym i w pełni kompetentnym (co nie zawsze znaczy najbardziej udanym) sprawowaniem funkcji politycznych"21. W stronnictwie krakowskim historycy byli równocześnie politykami, a niemal wszyscy działacze polityczni posiadali gruntowną wiedzę historyczną. W działalności tego stronnictwa nie jest wręcz możliwe oddzielenie nauki od polityki - one się ze sobą przeplatały ${ }^{22}$.

14 M. Jaskólski, Kaduceusz polski. Myśl polityczna konserwatystów krakowskich 1866-1934, Warszawa-Kraków 1990, s. 245.

15 Ibidem, s. 45.

16 W. Feldman, Stronnictwa i programy polityczne w Galicji, Kraków 1907, s. 210.

17 Ibidem, s. 211.

18 M. Jaskólski, Kaduceusz..., s. 45.

19 Sz. Rudnicki, Stowo o autorze [w:] W.L. J a w or s k i, Diariusz 1914-1918, Warszawa 1997, s. X-XI; J. Buszko, Jaworski Władysław Leopold [w:] Polski słownik biograficzny, t. 11, WrocławWarszawa-Kraków 1964, s. 115-118.

20 M. Jaskólski, Kaduceusz..., s. 30-45.

21 Ibidem, s. 17.

22 Ibidem, s. 58. 
Wydaje się jednak, że kluczową sprawą dla zrozumienia stosunku krakowskich konserwatystów do Austro-Węgier pozostają nie tyle ich rozważania historyczne, ile raczej przyjęta przez nich filozofia polityczna. W swoim zasadniczym założeniu doktryna stańczyków jawiła się jako typowa dla dziewiętnastowiecznego konserwatyzmu. Bliska im koncepcja państwa i społeczeństwa wynikała przede wszystkim z głębokiego antyindywidualizmu - przekonania o prymacie zbiorowości, a więc państwa, czy też narodu, nad jednostką ${ }^{23}$. Wiązała się z tym silna wizja organicystyczna, przez co rozumiemy ideę społeczeństwa jako naturalnego organizmu, w ramach którego każdy człowiek otrzymuje najlepsze warunki do życia ${ }^{24}$. Kolejną wartą wspomnienia zasadę stanowił ewolucjonizm - podkreślanie ciągłości społeczeństwa, państwa, tradycji, a także rozwój następujący w czasie i przestrzeni w sposób stopniowy. Postęp miał mieć charakter nie tyle gwałtownych zmian, ile bardziej harmonijnego narastania. Prawidłowo zachodzące zmiany społeczne widziano jako ciągły „ruch do góry”, tak więc - wbrew powszechnemu przekonaniu o pesymizmie szkoły krakowskiej - jej zasadnicza refleksja na temat ludzkości posiadała wydźwięk optymistyczny. Owo idealne, konserwatywne społeczeństwo, funkcjonujące jak żywy, stopniowo rozwijający się organizm, musiało się opierać na zasadzie harmonii i równowagi, co w praktyce oznaczało dążenie do łagodzenia wszelkich antagonizmów ${ }^{25}$. Nie przez przypadek w 1910 roku Władysław Leopold Jaworski pisał: ,[...] gdybyśmy stracili jedni do drugich wzajemne zaufanie, to wobec tego, że wszyscy widzimy, że tylko w drodze współdziałania przyjść może coś do skutku, sumienie nie pozwalałoby nam łudzić ludności, że cośkolwiek pozytywnego zrobimy"26.

Zarówno w swojej wizji rozwoju społecznego, jak i w praktycznej działalności politycznej stańczycy bardzo mocno podkreślali też konieczność oparcia się na elitach. Przyjmowano założenie, że stanem naturalnym i zarazem naczelną zasadą każdej struktury społecznej jest hierarchia. W ich ujęciu wypływało to zarówno z natury człowieka, jak i z historii, czy wreszcie religii, ze swej istoty wpajającej hierarchiczny obraz świata ${ }^{27}$. Jedną z konsekwencji takiego stanu rzeczy jest przyjęcie, że do harmonijnego funkcjonowania społeczeństwa potrzeba silnej „,warstwy przodkującej”, a więc grupy posiadającej równocześnie silną tożsamość narodową oraz zdolność do kształtowania państwowego bytu ${ }^{28}$. Owa „warstwa przodkująca” kojarzona była przede wszystkim z ziemiaństwem oraz elitami intelektualnymi.

Swoje przekonania o tym, jak powinno wyglądać i rozwijać się społeczeństwo, stronnictwo krakowskie nakładało na bieżącą, dramatyczną sytuację narodu polskiego. Nie będziemy się rozwodzić nad wielokrotnie już w literaturze omawianą stańczykowską analizą przyczyn upadku Rzeczypospolitej Obojga Narodów, warto

23 Ibidem, s. 55.

24 M. Jaskólski, Historia - naród - państwo. Zarys syntezy myśli politycznej konserwatystów krakowskich w latach 1866-1934, Kraków 1981, s. 73-74.

25 Ibidem, s. 89.

26 W.L. Jaworski, Listy z Sejmu. Rok 1910, Kraków 1911, s. 201.

27 M. Jaskólski, Kaduceusz..., s. 83-84.

28 Ibidem, s. 105; M. Król, Przedmowa [w:] Stańczycy. Antologia myśli spolecznej i politycznej konserwatystów krakowskich, wybór, przedm. i przyp. M. K ró1, Warszawa 1985, s. 20. 
jednak zwrócić uwagę, że w kontekście przytoczonych rozważań nad rozwojem cywilizacyjnym narodów, zarówno przed-, jak i porozbiorowe dzieje Polaków miały świadczyć o ogólnym „niedostatku charakteru narodowego"29. Ten pesymizm w myśleniu o własnym społeczeństwie wyrażało też przekonanie o „młodszości cywilizacyjnej narodu polskiego" 30 . W tej sytuacji ogromną szansą stała się dla Polaków monarchia austro-węgierska, w której rządzeniu mogli brać czynny udział, zarówno na poziomie krajowym, jak i ogólnopaństwowym. Sejm Krajowy, Rada Państwa oraz sprawowanie funkcji w rządzie mogły być dla przedstawicieli warstwy szlacheckiej nieocenioną szkołą funkcjonowania prawdziwego państwa. Dobitnie świadczą o tym słowa napisane już w czasie I wojny światowej przez Władysława Leopolda Jaworskiego:

Nie mieliśmy przez generacje wychowania polegającego na wyrabianiu zmysłu państwowości. Przeciwnie, państwo było nam wrogiem. Teorią nie można wyrabiać zmysłu państwowości, tu widzi się znaczenie stańczyków: wejść w rząd, wyrobić w sobie zmysł państwowości ${ }^{31}$.

Rząd, nawet jeśli był zaborczy, stawał się elementem spajającym społeczeństwo, scalał i nadawał sensowny kształt stosunkom społecznym. Krytyka władzy mogła prowadzić wyłącznie do anarchii - dawnego i największego grzechu społeczeństwa polskiego. Obywatelską cnotą było w tym układzie nic innego, jak tylko posłuszeństwo $^{32}$. Rozumując w ten sposób, stańczycy zaczęli wierzyć, że paradoksalnie podstawą rozwoju narodu polskiego jest właśnie państwo zaborcze.

Jak widzimy, lojalizm stańczyków nie był zatem lojalizmem bezrozumnym, wynikającym jedynie z wyczucia politycznej koniunktury. Jego uzasadnienie stanowił bowiem przemyślany, długofalowy i bardzo wyrafinowany projekt, polegający na budowaniu w ramach naddunajskiej monarchii narodu w sensie politycznym. Przyjęte przez nich założenia ideologiczne powodowały, że sytuacja, w jakiej po wprowadzeniu autonomii znaleźli się galicyjscy Polacy, wydawała się optymalna, wręcz idealna do dalszego, harmonijnego rozwoju narodu. W praktyce aż do okresu bezpośrednio poprzedzającego I wojnę światową wysiłki stronnictwa krakowskiego zmierzały do utrzymania za wszelką cenę ówczesnego, galicyjskiego stanu rzeczy. Najlepiej świadczą o tym słowa Stanisława Koźmiana:

[...] stan Galicji i jej stosunek do monarchii pozostały rękojmią ogólną dla idei polskiej [...]. Pielęgnujmy zatem ten stan wytrwale, sumiennie, pielęgnujmy troskliwie stosunek kraju z tą dynastią, pod egidą której rozwijać się możemy jako część i pracować dla całości³.

29 Ibidem, s. 62.

30 M. Bobrzyński, O potrzebie ,,silnego rządu w Polsce”, oprac. P. Majewski, Warszawa 2001, s. 52; J. Szujski, O młodszości naszego cywilizacyjnego rozwoju [w:] Stańczycy. Antologia myśli..., s. 149-159; M. Jaskólski, Historia..., s. 122.

31 Archiwum Polskiej Akademii Nauk (dalej: APAN), Materiały Władysława Leopolda Jaworskiego, Dyariusz 1914-1918, t. 3, k. 708.

32 W. Feldman, Stronnictwa..., s. 178.

33 S. Koźmian, Program „Czasu”. Artykut wstępny z dnia 27 VII 1878 r. (Przedruk z „Czasu” nr 171), Kraków 1878, s. 19-20. 
Mając już pewną jasność co do ideologicznych podstaw obozu konserwatywnego, które - jak widzimy - przekładały się na bardzo specyficzny sposób myślenia przedstawicieli orientacji prohabsburskiej na temat zjawiska państwa zaborczego, możemy podjąć próbę analizy konkretnych przykładów owej ,,austro-polskiej” tożsamości. Warto w tym momencie przyjrzeć się postawom trzech postaci, które w latach 1914-1918 odegrały bodaj największą rolę w realizacji działań obliczonych na realizację koncepcji odbudowy polskiej państwowości we współdziałaniu z monarchią Habsburgów. Mowa w tym miejscu o Władysławie Leopoldzie Jaworskim, Leonie Bilińskim oraz Michale Bobrzyńskim. Jakkolwiek mamy tu do czynienia z pewnym wyborem - niewielką próbką badawczą - pozwoli nam on poczynić pewne obserwacje, tym bardziej że każda z tych postaci reprezentowała nieco inny odcień interesującej nas, austro-polskiej tożsamości.

Władysław Leopold Jaworski, choć najmniej może znany, przywołany został jako pierwszy, gdyż to właśnie on, pełniąc funkcję prezesa Naczelnego Komitetu Narodowego, przez długi czas stał na czele struktury, która w okresie I wojny światowej w sposób najbardziej konsekwentny i jawny starała się umożliwić realizację koncepcji austro-polskiej. Spośród wszystkich ówczesnych polskich polityków to właśnie on podejmował na rzecz tej idei najwięcej praktycznych działań, absolutnie się zresztą z nią identyfikując. Nie uchylał się przy tym od żadnej politycznej odpowiedzialności, dzielnie brał na siebie wszelką możliwą krytykę, a swoim poglądom pozostał wierny aż do przesady - do końca - płacąc ostatecznie wysoką cenę, jaką było zniknięcie z polskiej polityki.

Ten znakomity znawca prawa cywilnego, profesor Uniwersytetu Jagiellońskiego, stanowił typowe dla środowiska krakowskich konserwatystów połączenie intelektualisty oraz polityka. Jego poglądy zawsze charakteryzowało dążenie do zachowania logiki, spójności i precyzji. Pośród badaczy idei politycznych pojawia się opinia, że był on najwybitniejszym ideologiem obozu neokonserwatywnego i jednym z niewielu, którzy zbudowali w miarę konsekwentną doktrynę ${ }^{34}$. Zarówno w pracy naukowej, jak i w działalności politycznej typowe dla niego pozostawało również godzenie intelektualnych, ideologicznych, emocjonalnych i wreszcie politycznych sprzeczności oraz budowanie wysublimowanych i wielowarstwowych planów. W latach poprzedzających wybuch wojny przewodził on obozowi konserwatystów krakowskich w Sejmie Krajowym oraz austriackiej Radzie Państwa. Najciekawsza część jego kariery rozpoczyna się jednak wraz z powstaniem 16 sierpnia 1914 roku Naczelnego Komitetu Narodowego. Jakkolwiek w samym powoływaniu tej organizacji do życia nie brał zbyt aktywnego udziału, to objął $\mathrm{w}$ niej funkcję przewodniczącego sekcji zachodniej. Pod koniec listopada 1914 r., w wyniku kryzysu, który doprowadził do odejścia pierwszego prezesa NKN Juliusza Leo, Jaworski stanął na czele tej organizacji.

W ciągu kolejnych tygodni polityk ten nadał Naczelnemu Komitetowi Narodowemu coś, czego niezmiernie mu dotychczas brakowało - wyrazistości ideologicznej, a konkretnie zajął jednoznaczne stanowisko, jeśli chodzi o przyszłość sprawy polskiej. W pierwszych miesiącach istnienia organizacji unikano raczej tego typu

34 M. Jaskólski, Kaduceusz..., s. 46-48. 
deklaracji i koncentrowano się na realizacji wystawiania i wspierania Legionów Polskich, co wynikało przede wszystkim z dążenia do zachowania kruchej równowagi pomiędzy ugrupowaniami jednoznacznie proaustriackimi a endecją wraz z jej sojusznikami ${ }^{35}$. Po tym, jak w październiku 1914 r. z NKN odeszła Narodowa Demokracja oraz Podolacy, Jaworski nie musiał się już tymi względami przejmować. Za jego sprawą krakowski Komitet zaczął w sposób jednoznaczny propagować ideę austro-polską, a pierwszą fazą realizacji tego programu miało być tworzenie Legionów Polskich. Prezes formułował założenia swojej polityki w tak kategoryczny sposób, że nie pozostawiało to żadnych wątpliwości: „Niezawisła Polska pod berłem dynastii Habsburgów w unii z austriacko-węgierską monarchią, oto program narodu polskiego, program Naczelnego Komitetu Narodowego, cel walk polskich legionów"36.

Należałoby w tym momencie zadać podstawowe pytanie: czy w podejściu Władysława Leopolda Jaworskiego można się dopatrzeć elementów emocjonalnego stosunku do Austrii? Czy też jego poglądy, choć wyraziste i zdecydowane, rozpatrywać trzeba wyłącznie w kategoriach podyktowanej chłodną analizą gry politycznej? Najpierw trzeba zauważyć, że w dostępnych nam, rozlicznych pismach, przemówieniach, listach, czy wreszcie pamiętnikach prezesa NKN, ów komponent emocjonalny rzeczywiście występuje. Rzadko jest on wprawdzie wyrażony wprost, poprzez konkretne sformułowania, ale zdecydowanie można go zauważyć, jeśli zwróci się uwagę na niezwykły, graniczący z fanatyzmem upór, z jakim w skrajnie niejasnej i szybko zmieniającej się sytuacji politycznej Władysław Leopold Jaworski propagował ideę austro-polską. Prezes NKN trzymał się tej koncepcji, choć w wyniku nowego, kształtującego się w latach 1914-1916 układu relacji pomiędzy monarchią Habsburgów i Niemcami, oznaczającego stopniowe uzależnienie Austro-Węgier od swojego potężnego sojusznika, stawało się jasne, że tworzenie państwa polskiego pod panowaniem Habsburgów będzie oznaczać nieuchronną zgodę na jaką́s formę związku z Hohenzollernami. Było to zresztą zgodne z popularną wówczas w Niemczech koncepcją Mitteleuropy, którą Jaworski począł propagować nawet nie tyle ze względu na nią samą, ile jako konsekwencję planu zbudowania właśnie habsburskiej Polski ${ }^{37}$. W 1915 roku o swojej wizji mówił zresztą otwarcie. Wyobrażał sobie, że Królestwo Polskie złączone zostanie pod berłem Habsburgów z Galicją, przy czym ów nowy twór będzie miał wpisany do konstytucji związek gospodarczy z Niemcami, a także sojusz z państwami centralnymi przeciw Rosji. Jaworski taką postawę uważał za najbardziej realistyczną. W odezwie wydanej w sierpniu 1915 roku po wkroczeniu wojsk niemieckich do Warszawy wprost stwierdzał: „Musimy przyznać, że przy uregulowaniu tych [tj. polskich] kwestii Niemcy i Austro-Węgry muszą strzec się swoich własnych interesów" ${ }^{38}$. Tego rodzaju postulaty, będące w istocie zgodą na uzależnienie przyszłej Polski od Niemiec, wywoływały pośród rozmówców

35 J. Buszko, Polacy w parlamencie wiedeńskim, Warszawa 1996, s. 299.

36 Archiwum Narodowe w Krakowie (dalej: ANK), Archiwum Naczelnego Komitetu Narodowego (dalej: NKN), sygn. 67 (mikrofilm 100.257), k. 50.

37 J. Buszko, Jaworski Wtadystaw..., s. 117.

38 ANK, NKN, sygn. 38 (mikrofilm 100.223), k. 41. 
Jaworskiego, i w ogóle w społeczeństwie polskim, sporą konsternację $e^{39}$. Nie jest w tym momencie naszym celem zgłębianie stosunku prezesa NKN do Niemiec, najistotniejszy pozostaje jednak fakt, że prezes krakowskiego Komitetu gotowy był na bardzo daleko idące kompromisy, aby tylko zrealizować swój cel nadrzędny - utworzenie habsburskiej Polski. O jego niezwykłej wprost determinacji świadczy również fakt, że o wprowadzeniu w życie tej idei Jaworski zupełnie poważnie myślał nawet w październiku 1918 roku, kiedy naddunajska monarchia znajdowała się w stanie rozkładu, o powstaniu nowego państwa polskiego mówiło się już głośno, a opcja prohabsburska nie miała w społeczeństwie polskim prawie żadnych zwolenników.

Wróćmy jednak do zasadniczego pytania: czy Jaworskiemu chodziło bardziej o Austrię, czy jednak o Polskę, której przyszłość widział po prostu w bardzo specyficzny dla siebie sposób? Przyznać należy, że w niektórych jego wypowiedziach przebija się ton ściśle państwowego patriotyzmu. W 1907 roku pisał: „W Austrii kierunek wpływu Polaków na politykę zagraniczną monarchii nie może ulec zmianie, w państwie bowiem liczącym tyle narodów nie może ona być polityką zagraniczną tego lub innego narodu, ale musi być polityką całego państwa" ${ }^{40}$. Tego rodzaju cytatów można u niego znaleźć więcej, ale znamienne jest, że pojawiają się one niemal wyłącznie w okresie przedwojennym, kiedy sprawa niepodległości Polski nie była jeszcze traktowana w kategoriach mającego szanse realizacji projektu politycznego, a polscy działacze bardzo głęboko zanurzeni byli w rzeczywistości naddunajskiej monarchii. Wybuch wojny światowej zmienił ten stan rzeczy diametralnie. W sierpniu 1914 roku, po utworzeniu Legionów Polskich oraz Naczelnego Komitetu Narodowego, bohater naszych rozważań zwierzał się swojemu przyjacielowi Janowi Hupce: „Sprawa polska stoi tak świetnie, że dziś płakałem jak dziecko" "41. A więc na pierwszy plan wysuwają się już emocje związane z patriotyzmem w odcieniu wyraźnie polskim.

Na tym nie koniec jednak związanych z Jaworskim niejednoznaczności. Analizując skomplikowaną tożsamość głównego propagatora idei związku z Habsburgami, należy zwrócić uwagę na jeszcze jeden znamienny moment. Co wydawać się może wręcz szokujące, w listopadzie i grudniu 1918 roku, kiedy po stu dwudziestu trzech latach pojawiało się niepodległe państwo polskie, Władysław Leopold Jaworski bynajmniej się z tego powodu nie cieszył. Jego pamiętniki przepełnione są goryczą, narzekaniem i głębokim przeświadczeniem o katastrofie europejskiej cywilizacji. Były już wówczas prezes NKN, choć po raz pierwszy w życiu funkcjonował pod całkowicie polską administracją, zadawał dramatyczne pytanie: „Dlaczego naród polski [jest] tak niezdolny do państwowego życia?" ${ }^{42}$. Wydaje się, że powstające państwo stanowiło zatem coś zupełnie innego niż to, o co Jaworskiemu chodziło. Aby jednak zrozumieć kontekst tych słów, należałoby przytoczyć też inne wypowiedzi z tej samej części jego pamiętnika: „Zwycięstwo Ameryki - to zwycięstwo koryta. Niech żyje żerowisko! Będziemy gnili w naszej ciasnocie, a patriotyzm okazywać będziemy

\footnotetext{
39 W.L. Jaworski, Dariusz..., s. 40.

40 W. Suleja, Orientacja..., s. 22.

41 J. Hupka, Z czasów wielkiej wojny. Pamiętnik nie-kombatanta, Lwów 1937, s. 14.

42 W.L. Jaworski, Diariusz..., s. 300.
} 
przez kopanie zdechłego Niemca”43. Potem zaś stwierdza: „Niemcy przez pierwsze lata wojny - ileż w tym piękna[...]"44, w innym miejscu pisze: ,[...] ostatnią ostoję autorytetu, Niemcy, rozwalili [...]"45. Czy zatem Jaworski był zatem proniemiecki? Otóż, biorąc pod uwagę całokształt jego wieloletniej, publicznej działalności, nic na to nie wskazuje! Pokazuje to jednak, że odchodzący w przeszłość świat kultury środkowoeuropejskiej, przede wszystkim niemieckojęzycznej, stanowił dla niego kwintesencję, uosobienie najwyższej cywilizacji europejskiej, opartej na myśli, prawie, kulcie państwa i jego możliwie najlepszej organizacji. Cywilizacji opartej wreszcie na starych, konserwatywnych wartościach, których całkowitym przeciwieństwem pozostawała nowoczesna, praktyczna i nastawiona na zysk kultura anglosaska. Z Jaworskiego wychodzi tu zatem nie tyle ukryty zwolennik Niemiec, ile epigon najbardziej klasycznego, dziewiętnastowiecznego konserwatyzmu. Interpretację tę potwierdzać może też inny cytat, odnoszący się do upadającej monarchii Hohenzollernów: „Wielki naród! Powtarzam te słowa mojemu dziennikowi, bo głupcy zrobiliby mnie zdrajcą. Ja przecież dla mojego narodu chciałbym takiej samej wielkości, a głupcy spychają nas do granic etnograficznych [...]"46. A więc w ujęciu Jaworskiego państwo wielkie nie mogło być w żadnym wypadku narodowe. Biorąc pod uwagę zarówno kontekst tych rozważań, jak i jego wcześniejsze wypowiedzi, stwierdzić można, że dla byłego prezesa NKN ideałem pozostawało państwo ponadnarodowe, konserwatywne i w ograniczonym tylko stopniu demokratyczne. Naczelną wartością było dla niego państwo, nie zaś naród.

Widzimy zatem, że nie sposób sprowadzać kwestii identyfikacji Władysława Leopolda Jaworskiego do prostej dychotomii wyrażającej się w pytaniu o prymat tożsamości polskiej nad austriacką albo austriackiej nad polską. Austria stanowiła dla niego uosobienie pewnego konceptu, idei, ale nie oznacza to, że darzył ją szczególnym rodzajem uczucia tylko dlatego, że była Austrią. Wyraźnie to widać, jeśli porównamy jego podejście z postawą innego polskiego polityka - Leona Bilińskiego.

Ten jeden z najbardziej wpływowych polityków polskich, jacy kiedykolwiek działali w Wiedniu, w momencie wybuchu I wojny światowej pełnił funkcję równocześnie wspólnego ministra skarbu Austro-Węgier oraz cywilnego namiestnika Bośni i Hercegowiny. Jego ówczesna pozycja w stolicy cesarstwa stanowiła zwieńczenie długiej kariery. Przez ponad 20 lat Biliński piastował w administracji państwowej eksponowane stanowiska: dyrektora Austriackich Kolei Państwowych (1893-1895), ministra skarbu Austrii (1895-1897 i 1909-1910) oraz gubernatora Banku Austro-Węgierskiego (1900-1909) ${ }^{47}$. Co jednak istotniejsze, był on jednym z najbardziej zaufanych ludzi sędziwego Franciszka Józefa I i ponoć niewielu mogło z nim konkurować, jeśli chodzi o ilość odbytych audiencji ${ }^{4}$. Do historii przeszedł jego udział

${ }^{43}$ Ibidem, s. 295.

44 Ibidem.

45 Ibidem, s. 300.

46 Ibidem, s. 295.

47 Zob. S. Głąbiński, Biliński Leon [w:] Polski stownik biograficzny, t. 2, Kraków 1936, s. 97-98;

Haus-, Hof- und Staatsarchiv (dalej: HHStA), SB NL Bilinski 1: Nachlass Biliński.

48 W. Łazuga, Kalkulować..., s. 333. 
w wydarzeniach, które bezpośrednio doprowadziły do wybuchu I wojny światowej. To właśnie Biliński brał udział w słynnym posiedzeniu rządu monarchii 7 lipca 1914 roku, kiedy to podjęta została decyzja o wystosowaniu do Serbii niezwykle ostrego ultimatum, a więc wkroczeniu przez Austro-Węgry na drogę, która nieuchronnie prowadziła do wojny. Podobno, choć nigdy nie zostało to ostatecznie potwierdzone, Biliński był jednym z ministrów opowiadających się za przyjęciem wobec Serbii zdecydowanego kursu ${ }^{49}$.

Wszystko to nie mogło pozostać bez wpływu na jego tożsamość. Ta oczywiście była różnie oceniana. Wielu Austriaków nigdy do końca nie wierzyło w jego „austriackość”. Ponoć jeden z wysokich urzędników Ministerstwa Spraw Zagranicznych Aleksander Hoyos miał o nim powiedzieć, że jak każdy Polak myślał przede wszystkim o wyzwoleniu Polski ${ }^{50}$. Polacy z kolei nigdy nie wierzyli w jego polskość, traktując go jako absolutnie oddanego monarchii karierowicza. Jak twierdził w swoich pamiętnikach Jaworski, polscy irredentyści wprost uważali Bilińskiego za Austriaka, który w imię interesów monarchii gotów był w każdej chwili poświęcić sprawę polską. Jak stwierdził prezes NKN: ,instynktem czują tę austriackość niepodległościowcy u niego" "51. Ponoć Ignacy Daszyński rozpowiadał w 1918 roku w Krakowie, że nasz bohater nazywał sam siebie „Alter Österreicher" ${ }^{2}$. Jeśli chodzi o wypowiedzi samego Bilińskiego, to we wspomnieniach chętnie podkreślał on swoje zaangażowanie na rzecz sprawy polskiej, pisząc między innymi: „Od wybuchu wojny przestałem być z konieczności dziejowej ministrem bośniackim, a stałem się faktycznie ministrem polskim [...]" ${ }^{\prime 53}$. Problem polega jednak na tym, że jego pamiętniki zostały spisane oraz wydane już po zakończeniu I wojny światowej i powstaniu niepodległego państwa polskiego, kiedy to powszechnie wówczas nielubiany Biliński najprawdopodobniej próbował się po prostu bronić i podkreślać swój udział w procesie dochodzenia do niepodległości. Tego rodzaju patriotyczne deklaracje nie były mu zresztą obce już w czasie wojny. W odbywanych w styczniu 1915 roku prywatnych rozmowach buńczucznie stwierdzał, że domaga się powstania sejmu w Warszawie, co nie zmienia faktu, że jego rozmówcy podejrzewali, że były to słowa nieszczere, zaś prawdziwym celem Bilińskiego pozostawało objęcie prezesury Koła Polskiego, a więc dalsze funkcjonowanie w kręgu polityki wiedeńskiej ${ }^{54}$.

Rozmaite deklaracje i wypowiedzi, jak zwykle zresztą, nie dają nam jednoznacznego obrazu tożsamości Bilińskiego. Przyjrzyjmy się zatem jego politycznej działalności. I w tym przypadku możemy mówić o braku wyraźnie zarysowanego obrazu. Nie ulega bowiem najmniejszej wątpliwości, że w pierwszych tygodniach wojny Biliński faktycznie podejmował działania, które mogłyby sugerować jego autentyczne

49 L. Biliński, Wspomnienia i dokumenty 1846-1919, t. 1, Warszawa 1924, s. 289; Protokolle des Gemeinsamen Ministerrates der Österreichisch-Ungarischen Monarchie (1914-1918), Hg. M. Komjáthy, Budapest 1966, s. 141-150.

\footnotetext{
50 W. Łazuga, Kalkulować..., s. 337.

51 W.L. Jaworski, Diariusz..., s. 36.

52 L. Biliński, op. cit., t. 2, s. 176.

53 Ibidem, t. 1, s. 293.

54 W.L. Jaworski, Diariusz..., s. 27.
} 
zaangażowanie w sprawy polskie. W dniach 11-12 sierpnia 1914 roku to właśnie on, wraz Juliuszem Leo, prowadził w Wiedniu rozmowy, które ostatecznie doprowadziły do utworzenia Legionów Polskich oraz Naczelnego Komitetu Narodowego ${ }^{55}$. W następnych dniach, tym razem wraz z Michałem Bobrzyńskim, podjął on z kolei intensywne działania na rzecz wydania przez Franciszka Józefa I odezwy zapowiadającej utworzenie suwerennego, związanego z Austro-Węgrami państwa polskiego. Ze względu na sprzeciw premiera Węgier Istvána Tiszy pomysł ten ostatecznie nie został zrealizowany, niemniej jednak zaangażowanie Bilińskiego na rzecz jego realizacji nie budzi żadnych wątpliwości.

W okresie późniejszym postawę Bilińskiego trudno jednak określić jako jednoznacznie propolską. Nie wszedł on do Naczelnego Komitetu Narodowego, choć formalnie mu sprzyjał i popierał $\mathrm{w}$ Wiedniu jego politykę. $\mathrm{Z}$ wypowiedzi Jaworskiego wynika, że - podobnie jak wspomniany już Michał Bobrzyński - stanowił on swego rodzaju instytucję samą w sobie ${ }^{56}$. Zmiany w politycznej karierze Bilińskiego przyniosła jednak zima 1914/1915. Najpierw w wyniku gabinetowych przesunięć oraz wzrostu wpływów węgierskiego premiera Tiszy utracił on funkcję wspólnego ministra skarbu monarchii habsburskiej. Niedługo później zrekompensował sobie w pewien sposób tę porażkę poprzez objęcie po Juliuszu Leo prezesury Koła Polskiego ${ }^{57}$. Ze względu na warunki wojenne struktura ta w rzeczywistości wówczas nie funkcjonowała. Biliński zmienił to jednak, powołując do życia tak zwaną Komisję Polityczną Koła - grono, które mogło się zbierać i działać niezależnie od sesji parlamentarnych ${ }^{58}$. Równocześnie Komisja ta zawarła z NKN porozumienie o politycznej współpracy.

Stopniowo, w roku 1915 Biliński zaczął jednak prowadzić politykę ewidentnie krakowskiemu Komitetowi niechętną, występując z pozycji jeszcze bardziej lojalistycznych i konserwatywnych niż NKN, uchodzący przecież za uosobienie prohabsburskiej postawy ${ }^{59}$. Biliński uznał działalność tej organizacji za zbyt odważną, żeby nie rzec - nieodpowiedzialną i dla sprawy polskiej szkodliwą. Stał on na stanowisku, że to nie NKN, ale parlamentarne Koło Polskie powinno być najważniejszą instytucją, która w warunkach wojennych miała reprezentować społeczeństwo oraz aspiracje Galicji ${ }^{60}$. Jesienią oraz zimą 1915 roku Biliński prowadził z prezesem NKN negocjacje, w czasie których za pomocą różnego rodzaju argumentów, w tym również emocjonalnych szantaży, zmusił go do podpisania porozumienia o połączeniu obu polskich organizacji ${ }^{61}$. W praktyce ugoda ta oznaczała, że NKN miał się zajmować wyłącznie sprawami wystawiania Legionów Polskich, a rolę zasadniczego ośrodka politycznego Galicji miało od tej pory odgrywać wyłącznie Koło Polskie ${ }^{62}$. Jeden

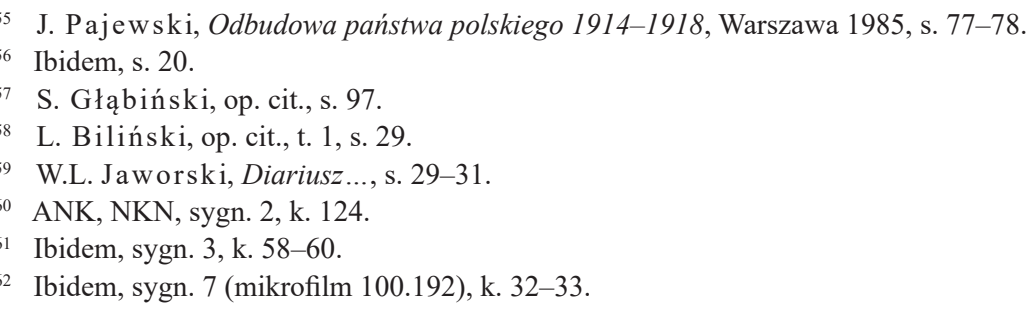


z działaczy krakowskiego Komitetu dosadnie stwierdził, że został on sprowadzony do instytucji „kupowania spodni dla legionistów”63. W opinii Jaworskiego Biliński zupełnie nie rozumiał przy tym idei Legionów Polskich i traktował je jak zwykłe polskie pospolite ruszenie, nie zaś - jak było to powszechnie wówczas odbierane symbol narodowy ${ }^{64}$. Diagnozę tę potwierdzają dokumenty z ówczesnej działalności Komitetu, którą Biliński, choć formalne to on został wówczas prezesem, zupełnie się nie interesował. Wspomniane wydarzenia pokazują, że pomimo licznych deklaracji o oddaniu sprawie polskiej Biliński rozgrywał ją w Wiedniu w taki sposób, aby nie ucierpiały interesy monarchii i aby jego własna pozycja polityczna wyraźnie się umocniła.

Jego pamiętniki, jak już wspomniano, pozornie nie dają jasnego obrazu. Wypełniają je niezwykle szczegółowe opisy relacji w austro-wegierskich kręgach rządowych. O Polsce i sprawie jej niepodległości pisał niewiele i nie można się oprzeć wrażeniu, że przedmiotem jego zainteresowania pozostawały właśnie Austro-Węgry oraz jego własna kariera urzędnicza. Tworząc swoje pamiętniki, Biliński wprawdzie niezmiernie uważał, aby nie używać sformułowań, które wprost wskazywałyby na jego austriacką identyfikację, ale nie sposób zaprzeczyć, że o wszystkim, co wiązało się z naddunajską monarchią, pisał z trudną do ukrycia sympatią. Jeśli więc weźmiemy pod uwagę zarówno wydźwięk rozmaitych wypowiedzi, jak i całokształt jego politycznej działalności, pojawia się obraz człowieka, który faktycznie identyfikował się przede wszystkim z Austrią. Swoje polskie pochodzenie traktował z pewnego rodzaju sentymentem i do pewnego stopnia był skłonny działać na rzecz swojej pierwszej ojczyzny, tym bardziej że liczne, polskie środowisko polityczne w Wiedniu stanowiło doskonałą odskocznię do walki o jego pozycję w kręgach rządowych. Nie zmienia to faktu, że w przeciwieństwie do wielowymiarowego Władysława Leopolda Jaworskiego, jego tożsamość była już jednoznacznie habsburska.

Różnicę między podejściem obu tych polityków najlepiej obrazuje zresztą cytat pochodzący z pamiętnika Jaworskiego:

Dziwne państwo ta Austria. „My ją kochamy” - mówi Biliński. „Kochamy”... Faktem jest, że tylko w Austrii, państwie narodowo niejednolitym, możemy pozostać odrębnym narodem, Rosja nas zdemoralizuje, Prusy zetrą na miazgę. [...] Mówiono mi, że na zebraniu u Niezabitowskiego powiedział Gołuchowski: „Kto nie idzie z Austrią, jest złym Polakiem”. Ma rację, ale nie wysnuwa konsekwencji... ${ }^{65}$.

Słowa te doskonale pokazują postawę Jaworskiego. Na pierwszym miejscu w jego systemie wartości oraz identyfikacji znajdowała się jednak Polska, ale... głęboko wierzył, że nie mogło być Polski bez Austrii. Biliński Austrię kochał. Jaworski kochał Polskę, ale nie widział dla niej innej drogi, jak związek z państwem Habsburgów. Pierwszy był więc de facto patriotą austriackim, drugi - patriotą austro-polskim.

Pozostaje nam jeszcze do rozpatrzenia trzecia z przytoczonych postaci - Michał Bobrzyński, jeden z czołowych historyków szkoły krakowskiej, ale też namiestnik

\footnotetext{
63 Ibidem, sygn. 2, k. 125-127.

${ }^{64}$ W.L. Jaworski, Diariusz..., s. 41.

65 Ibidem, s. 17-18.
} 
Galicji w latach 1908-1913, cieszący się w omawianym przez nas okresie ogromnym szacunkiem i autorytetem, zarówno w Galicji, jak i na wiedeńskim dworze. Warto poświęcić mu nieco uwagi, gdyż uchodził on za „duchowego ojca” obozu neokonserwatywnego. Charakterystyczne jest jednak, że przed wybuchem wojny Bobrzyński niewiele o idei austro-polskiej pisał. Niezmiernie trudno jest znaleźć potwierdzenie, że szczegóły koncepcji austro-polskiej szerzej go zajmowały. Jego ówczesne poglądy można częściowo odtworzyć na podstawie późniejszych wypowiedzi, przede wszystkim zawartych w wydanej już w 1920 roku książce Wskrzeszenie państwa polskiego ${ }^{66}$. Tymczasem w napisanych jeszcze w 1913 roku pamiętnikach niewiele uwagi poświęca on sprawom międzynarodowym czy nawet państwowym, całkowicie poświęca się natomiast polityce krajowej. O związkach Polaków z Austrią pisał jak o czymś absolutnie oczywistym, niewymagającym prawdopodobnie szerszego komentarza. Stwierdzał choćby, że narodowi demokraci „gotowi byli i ten stosunek [tzn. Polaków do Austrii], jedyną ostoję naszego narodowego bytu, podrzeć i pozycję naszą w Austrii na szwank narazić [...]"67. Znacznie częściej niż o przyszłości sprawy polskiej wypowiadał się Bobrzyński na temat zgubnych skutków moskalofilizmu, do którego wprost ział nienawiścią ${ }^{68}$.

O jego stosunku do Austrii pośrednio świadczy również to, co pisał na temat gwałtownie rozwijających się w Galicji organizacji strzeleckich. Stwierdzał: „Ideały polskie, które się snuły w umysłach naszej młodzieży, nie raziły w obliczu wojny, bo szły z Austrią" ${ }^{69}$. A więc, w opinii Bobrzyńskiego, polskie wysiłki niepodległościowe, aby w ogóle mogły zyskać jego uznanie, musiały przede wszystkim posiadać walor lojalizmu w stosunku do Austrii. Jego poglądy na temat organizacji strzeleckich uległy zresztą pewnej ewolucji, z tym że cały czas poddawał je ocenie z punktu widzenia związku Polaków z monarchią. Obawiał się, że gdyby spodziewana w roku 1913 wojna nie wybuchła, pośród strzelców mogłaby się pojawić niechęć wobec Austrii. Oznaczałoby to „zmącenie stosunku, jaki Polaków łączył z Austrią"70. A więc kwestie te znów rozpatrywane były przede wszystkim z punktu widzenia nienaruszalności związku Polaków z monarchią.

Źródeł tej niechętnej postawy namiestnika wobec związków strzeleckich oraz KSSN szukać należy w jego wizji państwa, którą zarysował już w swoich pracach historycznych i której pozostał wierny właściwie przez całe życie. Państwo musiało być silne, sprawne i dobrze zarządzane ${ }^{71}$. W tym momencie dziejowym, w jakim znajdowali się Polacy pod zaborami, jedynym państwem, jakie „posiadali”, była

${ }^{66}$ W książce tej Bobrzyński pisał: ,[...] Austria i Węgry, zagrożone okoleniem na Bałkanach przez Rosję, zmuszone będą do wojny we własnej obronie, a tylko podniesieniem sprawy polskiej zadać mogą stanowczy cios Rosji. Przygotowaniem do tej akcji było nadanie Galicji swobód narodowych i zaprowadzenie w niej rządów polskich. Polska odbudowana miała się złączyć z Austrią i Węgrami i znaleźć w nich oparcie", zob.: M. Bobrzyński, Wskrzeszenie państwa polskiego, Warszawa 1920, s. 7.

67 M. Bobrzyński, Z moich pamiętników, oprac. A. Galos, t. 2, Warszawa 2006, s. 181.

68 W. Łazuga, Ostatni stańczyk. Michat Bobrzyński - portret konserwatysty, Toruń 2005, s. 155.

${ }_{69}$ M. Bobrzyński, $Z$ moich..., t. 2, 2006, s. 185.

70 Ibidem.

71 W. Łazuga, Ostatni stańczyk..., s. 37. 
Austria. Dawała ona realną możliwość samodzielnego zarządzania całą prowincją i decydowania o jej sprawach zewnętrznych, a także dopuszczała do rządów na poziomie centralnym. Cel nadrzędny stanowiło utrzymanie możliwości udziału Polaków w zarządzaniu państwem oraz krajem. To było absolutnie najważniejsze, dlatego Bobrzyński nie wahał się podejmować energicznych i kontrowersyjnych działań, aby ten stan rzeczy utrzymać i zwalczyć wszystko, co mogłoby mu zaszkodzić. Jeśli dla stabilizacji Galicji konieczne było osiągnięcie kompromisu z Ukraińcami - nie miał wątpliwości, że należy do niego dążyć. W jego ujęciu ważniejsze było funkcjonowanie w Galicji sprawnej administracji niż określanie tego terytorium jako „polskiej” prowincji. Gdy zaś uznał, że ruch strzelecki stanowił zagrożenie dla stabilności sytuacji - też nie miał oporów, aby przeciw niemu występować, choć trzeba przyznać, że działania te prowadził z nikłym powodzeniem, głównie dlatego, że organizacje paramilitarne znajdowały się wówczas pod parasolem ochronnym austriackiego wywiadu $^{72}$. W grudniu 1912 roku Bobrzyński włożył z kolei wiele wysiłku w przyjęcie przez Koło Polskie uchwały zapewniającej o całkowitej lojalności Polaków wobec monarchii na wypadek wojny ${ }^{73}$. W swoich pamiętnikach podkreślał, że uchwała ta, wiążąc sprawę polską ze sprawą Austrii, była potępieniem polityki endeków, która Polaków odwodziła od Austrii i przeciw niej burzyła ${ }^{74}$. Znamienne jest zatem, że w okresie przedwojennym Bobrzyński nie rozwijał specjalnie koncepcji utworzenia związanego z Austrią państwa polskiego, jak czynił to jego przyjaciel Jaworski. Jedyne, co się dla niego liczyło, to absolutna i wolna od jakichkolwiek podejrzeń lojalność Polaków w stosunku do Habsburgów.

Pewną zmianę akcentów w jego politycznej postawie przyniósł wybuch I wojny światowej. W sierpniu 1914 roku Bobrzyński nie przyjął proponowanej mu funkcji cywilnego namiestnika Królestwa. Wynikało to z faktu, że nie został spełniony jego postulat, aby do skutku doszedł układ z Niemcami gwarantujący niepodzielność Królestwa Polskiego ${ }^{75}$. W innym momencie, zapytany, czy dać broń Piłsudskiemu, z pełnym przekonaniem odpowiedział: „dać" ${ }^{\text {" }}$. A więc w momencie wybuchu wojny już w sposób jednoznaczny na pierwszy plan wysunęła się kwestia przyszłości sprawy polskiej.

W okresie późniejszym Bobrzyński nieodmiennie strzegł interesów NKN w Wiedniu, oficjalnie nie angażując się w jego działalność, przede wszystkim po to, by posiadać swobodę objęcia jakiegoś poważniejszego stanowiska związanego $\mathrm{z}$ ewentualną odbudową państwa polskiego ${ }^{77}$. W rozwiązanie austro-polskie wierzył zresztą do końca wojny. Propagował je, publikując w 1916 roku mało dziś znane pozycje: O nasza przyszłość. Rozmowa między trzema Polakami: z Warszawy, Poznania

72 Ibidem, s. 138-139.

73 W. Suleja, Orientacja.., s. 11; K. Srokowski, op. cit., s. 58.

74 M. Bobrzyński, Z moich..., t. 2, 2006, s. 197.

75 W. Łazuga, Ostatni stańczyk..., s. 153; zob.: Biblioteka Jagiellońska (dalej: BJ), sygn. 8099/III (mikrofilm P-348/3), Korespondencja Michała Bobrzyńskiego z lat 1915-1919, k. 168.

76 W. Łazuga, Ostatni stańczyk..., s. 151.

77 Ibidem, s. 160. 
i Krakowa, a także Dialog o zasadach i kompromisach ${ }^{78}$. Nad poważnymi szansami realizacji tej koncepcji debatował z innymi politykami jeszcze we wrześniu 1918 roku w Krakowie ${ }^{79}$. W koncepcji tej były namiestnik nie widział jedynie drogi do stworzenia państwa polskiego, ale też sposób na jego utrzymanie. We Wskrzeszeniu państwa polskiego pisał: ,[...] bez tego związku groziłoby Polsce, nawet zjednoczonej, że będzie zgniecioną przez dwa takie kolosy jak Rosja i Niemcy, a chcąc tego uniknąć, będzie musiała oddać się jednemu z nich w opiekę i zależność" "80.

Postawa Bobrzyńskiego wydaje się zatem pod wieloma względami zbieżna z podejściem Jaworskiego. Obu, jak już wspomniano, określić można jako patriotów austro-polskich $\mathrm{w}$ tym sensie, że na pierwszym miejscu stawiali przyszłość sprawy polskiej, przy czym towarzyszyło im niezmącone niczym przekonanie, że jest ona możliwa tylko w ramach monarchii. Dopóki istniała monarchia, politycy ci nie wyobrażali sobie jakiejkolwiek formy bytu narodowego poza nią. Bez wątpienia chodziło im o Polskę i paradoksalnie dlatego pozostawali wierni Habsburgom. Obaj wywodzili swoją postawę z wielowarstwowej, wysublimowanej i mocno konserwatywnej historiozoficzno-politycznej koncepcji stańczyków. Jedyna różnica, jeśli chodzi o rozkład akcentów, polegała na tym, że Bobrzyński nieco mocniej podkreślał swoje przywiązanie do dynastii Habsburgów i do monarchii w ogóle ${ }^{81}$. Nadrzędność polskiego oblicza ich patriotyzmu wyrażała się natomiast w tym, że obaj politycy potrafili się powstrzymać od obejmowania eksponowanych stanowisk, jeśli było to sprzeczne z celem nadrzędnym, jaki stanowiło dobro sprawy polskiej, rzecz jasna specyficznie przez nich rozumiane. Wyraźnie odróżniali się tym od Leona Bilińskiego, ponieważ on tego rodzaju oporów nie miał. Możliwe, że był jedynym wpływowym politykiem, o którym możemy powiedzieć, że faktycznie stał się Austriakiem.

Musimy mieć świadomość, iż w okresie tym nie tylko Jaworski, Biliński i Bobrzyński tworzyli obóz prohabsburski. Lojalistycznymi deklaracjami przesiąknięta była niemalże cała galicyjska polityka, zarówno przed I wojną światową, jak i w jej trakcie ${ }^{82}$. Nie przez przypadek jeszcze w 1910 roku pismo satyryczne „Diabeł” zamieściło ką́śliwy slogan: „Od Krakowa po Podhajce - same zdrajce” ${ }^{\text {. Te }}$ trzy postacie wydają się jednak o tyle interesujące, że posiadały one realny wpływ na austro-polską politykę, i to zarówno na jej stronę teoretyczną, jak i na praktyczne działania. Co warto podkreślić, w ideę tę wierzyli oni tak mocno, że w wielu momentach chodziło tu o coś więcej niż tylko primum non nocere. W ich ujęciu dobro Austrii było bowiem najczęściej tożsame z dobrem Polski. Powtarzane przez niektó-

78 M. Jaskólski, Kaduceusz..., s. 180.
79 W. Lazuga, Ostatni stańczyk..., s. 179.
80 Ibidem.
$81 \quad$ Ibidem, s. 139.
$82 \quad$ Jako jeden z setek przykładów podać można choćby wypowiedź konserwatywnego Andrzeja Lubomirskiego z 6 lipca 1917 r. na forum izby poselskiej parlamentu austriackiego: „Pokładamy ufność naszą w Monarsze [...], któremu oby Bóg udzielił mocy do uświetnienia mocy i potęgi Habsburgów jednym z największych czynów dziejowych: odbudowy silnej, wielkiej i szczęśliwej Polski”, cyt. za: A.A. Zięba, op. cit., s. 71.

83 Cyt. za: ibidem, s. 62. 
rych historyków, pochodzące jeszcze sprzed 1914 roku, tezy, że szeroko pojętych konserwatystów krakowskich traktować należy jak „,polityków bardziej austriackich niż polskich", stanowią jednak krzywdzące uproszczenie i nie oddają całej złożoności sprawy ${ }^{84}$. Tożsamość tych ludzi możemy raczej określić jako łączoną, wielostopniową i bardzo dla poprzednich epok typową. Przegrali w politycznej walce między innymi dlatego, że w przeszłość wówczas odchodził ten sposób postrzegania świata. Następował koniec epoki gente..., natione... (tutaj można wstawić wiele różnych określeń). Rozpoczynał się czas tożsamości jednoznacznych, jednowymiarowych, przybierających najczęściej postać wszelkich odcieni nacjonalizmów.

\section{BIBLIOGRAFIA}

\section{I. Źródła}

\section{1. Źródła archiwalne}

Archiwum Narodowe w Krakowie (ANK)

Archiwum Naczelnego Komitetu Narodowego (NKN), sygn. 2, 3, 7, 38, 67.

Archiwum Polskiej Akademii Nauk w Warszawie (APAN)

sygn. III-82: Materiały Władysława Leopolda Jaworskiego, Dyariusz 1914-1918.

Biblioteka Jagiellońska (BJ)

sygn. 8099/III: Korespondencja Michała Bobrzyńskiego z lat 1915-1919.

Haus-, Hof- und Staatsarchiv in Wien (HHStA)

sygn. SB NL Bilinski 1: Nachlass Biliński.

\section{2. Źródła drukowane}

Dokumenty Naczelnego Komitetu Narodowego 1914-1917, Kraków 1917.

J a w or s k i W.L., Mowy 1914-1915, Kraków 1915.

Listy Władysława Sikorskiego do Władysława L. Jaworskiego i Prezydium Naczelnego Komitetu Narodowego (1914-1919), oprac. i wstęp Z. K o z i ń s k i, Z. P i e tr z y k, Kraków 1987.

Protokolle des Gemeinsamen Ministerrates der Österreichisch-Ungarischen Monarchie (1914-1918), Hg. M. K o m já th y, Budapest 1966.

Stańczycy. Antologia myśli społecznej i politycznej konserwatystów krakowskich, wybór, przedm. i przyp. M. K ró 1, Warszawa 1985.

\footnotetext{
84 J. Holzer, J. Molenda, Polska w pierwszej wojnie światowej, Warszawa 1963, s. 45.
} 


\section{Pamiętniki, wspomnienia}

B i l ińs k i L., Wspomnienia i dokumenty 1846-1919, t. 1, Warszawa 1924.

B obrzyń s ki M., Z moich pamiętników, oprac. A. Galos, t. 2, Warszawa 2006.

D a s zy ń s k i I., Pamiętniki, t. 2, Warszawa 1957.

Dąb s k i J., Wojna i ludzie, Wspomnienia z lat 1914-1915, Warszawa 1969.

Głąb iński S., Wspomnienia polityczne, cz. 2, Pelpin 1939.

H u p k J., Z czasów wielkiej wojny. Pamiętnik nie-kombatanta, Lwów 1937.

J a w o r s k i W.L., Diariusz 1914-1918, Warszawa 1997.

J a w o r s k i W.L., Listy z Sejmu. Rok 1910, Kraków 1911.

Polska w pamiętnikach Wielkiej Wojny, oprac. M. S o k oln i c k i, Warszawa 1925.

S ok oln icki M., Rok czternasty, Londyn 1961.

S tar ze w s k i R., Dziennik. Listopad 1914-marzec 1915, Kraków 2007.

\section{Opracowania}

B a tow s k i H., Rozpad Austro-Węier 1914-1918, Kraków 1982.

B in d e r H., Galizien in Wien. Parteien, Wahlen, Fraktionen und Abgeordnete im Übergang zur Massenpolitik, Wien 2005.

B o brzyń s k i M., Wskrzeszenie państwa polskiego, Warszawa 1920.

B o br z y ń s k i M., O potrzebie ,silnego rzadu w Polsce”, oprac. P. Majewski, Warszawa 2001, s. 52; J. Szujski, O młodszości naszego cywilizacyjnego rozwoju [w:] Stańczycy. Antologia myśli..., s. 149-159; M. Jaskólski, Historia ..., s. 122.

B u s z k o J., Jaworski Władysław Leopold [w:] Polski słownik biograficzny, t. 11, WrocławWarszawa-Kraków 1964, s. 115-118.

B u s z k o J., Polacy w parlamencie wiedeńskim, Warszawa 1996.

D ą brow s ki J., Wielka Wojna 1914-1918, t. 1-2, Warszawa 1937.

Drozdows ki M., Akcja zagraniczna Naczelnego Komitetu Narodowego (1914-1917), „Studia Historyczne” R. 53, 2010, z. 2, s. 161-181.

Drozdow s ki M., Dylematy polityki Naczelnego Komitetu Narodowego wobec Niemiec, „Studia Historyczne” R. 55, 2012, z. 1, s. 27-50.

D ro z d o w s k i M., Naczelny Komitet Narodowy. Pierwsza struktura nowego państwa czy przeżytek epoki zaborów? [w:] Front Wschodni I wojny światowej. Studia z dziejów militarnych i polityczno-społecznych, red. M. B a c z k o w s k i, K. R u s z a ła, Kraków 2013, s. 207-220.

Dro zd ow s k i M., Udziat Naczelnego Komitetu Narodowego w tworzeniu zaplecza logistyczno-organizacyjnego Legionów Polskich [w:] Prace Komisji Historii Wojen i Wojskowości PAU, t. 9, red. W. R o j e k, Kraków 2015, s. 29-44.

F e ld m a n W., Dzieje polskiej myśli politycznej 1864-1914, Warszawa 1933.

F e ld m an W., Ewolucje partyjne w Galicji, „Krytyka” 1912, t. 33, s. 205-215.

F e ld m a n W., Stronnictwa i programy polityczne w Galicji, Kraków 1907.

G a r l i c k i A., Józef Pitsudski (1867-1935), Kraków 2012.

G a rl i c k i A., U źródeł obozu belwederskiego, Warszawa 1983.

Gaul J., Stużby wywiadowczo-informacyjne Austro-Węier wobec radykalnego ruchu niepodlegtościowego w Królestwie Polskim 1914-1918, Warszawa 2006.

Głą b i ń s k i S., Biliński Leon [w:] Polski słownik biograficzny, t. 2, Kraków 1936, s. 97-98. 
Gro d z i s k i S., Sejm krajowy galicyjski, t. 1-2, Warszawa 1993.

Grodzi s k i S., W Królestwie Galicji i Lodomerii, Kraków 1976.

Gro s f e ld L., Polityka państw centralnych wobec sprawy polskiej w latach pierwszej wojny światowej, Warszawa 1962.

Holzer J., Mole n d a J., Polska w pierwszej wojnie światowej, Warszawa 1963.

Inwentarz Archiwum Naczelnego Komitetu Narodowego, oprac. L. Ł y s i k, A. P t a śn ik ow a, H. Z a j ą c ow a, Warszawa 1958.

J a s k óls k i M., Historia - naród - państwo. Zarys syntezy myśli politycznej konserwatystów krakowskich w latach 1866-1934, Kraków 1981.

Jaskóls ki M., Kaduceusz polski. Myśl polityczna konserwatystów krakowskich 1866 1934, Warszawa-Kraków 1990.

Ja skólsk i M., Konserwatyzm - nacjonalizm. Studia nad konfrontacjami ideowymi konserwatyzmu krakowskiego i demokracji narodowej przed 1914 r., Kraków 1989.

K n e b e 1 J., Rząd pruski wobec sprawy polskiej w latach 1914-1918, Poznań 1963.

Koźmian S., Program „Czasu”. Artykut wstępny z dnia 27 VII 1878 r. (Przedruk z „Czasu” nr 171), Kraków 1878.

K ról M., Przedmowa [w:] Stańczycy. Antologia myśli społecznej i politycznej konserwatystów krakowskich, wybór, przedm. i przyp. M. K ró 1, Warszawa 1985.

Król-M a u r R., Idea odrodzonego państwa polskiego w pogladach galicyjskich ugrupowań politycznych do utworzenia Naczelnego Komitetu Narodowego, „Politeja” 2010, nr 14, s. 269-300.

Litw in - L e w and ow s k a D., O polska rację stanu $w$ Austrii. Polacy $w \dot{z} y c i u$ politycznym Austrii w okresie monarchii dualistycznej (1867-1918), Lublin 2008.

L udwikowski R.R., Główne nurty polskiej myśli politycznej 1815-1890, Warszawa 1982.

Ludwikowski R.R., Szkice na temat galicyjskich ruchów i myśli politycznej (18481892), Warszawa 1980.

L u k in i c h E., Stanowisko rządu węgierskiego wobec kwestii polskiej w pierwszych latach wojny światowej, „Kwartalnik Historyczny” R. 52, 1938, z. 4, s. 609-644.

Ł a z u g W., Kalkulować. Polacy na szczytach c.k. monarchii, Poznań 2013.

Ł a z u g a W., Ostatni stańczyk. Michat Bobrzyński - portret konserwatysty, Toruń 2005.

Milew ska W., N o w a k J.T., Z i e n tar a M., Legiony Polskie 1914-1918. Zarys historii militarnej i politycznej, Kraków 1998.

P ająk J.Z., Od autonomii do niepodległości. Kształtowanie się postaw politycznych i narodowych społeczeństwa Galicji w warunkach Wielkiej Wojny 1914-1918, Kielce 2012.

P a j e w s k i J., Odbudowa państwa polskiego 1914-1918, Warszawa 1985.

P a j e w s k i J., Pierwsza wojna światowa, Warszawa 1998.

$\mathrm{Paj}$ e w s k i J., Polityka mocarstw centralnych wobec Polski podczas pierwszej wojny światowej, „Roczniki Historyczne” R. 28, 1962, s. 24-30.

Purchla J., Galicja po Galicji, czyli o niezwykłości mitu zaginionego królestwa [w:] Mit Galicji, red. J. Purchla, W. Ko s, Ż. Kom ar, M. Ry diger, W.M. S chwarz, Kraków 2014, s. 89-93.

Rudnicki Sz., Stowo o autorze [w:] W.L. Jaw orski, Diariusz 1914-1918, Warszawa 1997.

S ro k o w s k i K., N.K.N. Zarys historii Naczelnego Komitetu Narodowego, Kraków 1923.

S u le j a W., Józef Pitsudski, Wrocław 2005.

$\mathrm{S}$ u $1 \mathrm{ej}$ a W., Orientacja austro-polska w latach I wojny światowej (do aktu 5 listopada 1916 roku), Wrocław 1992. 